\title{
35. Karanlık bir ruhun ıstırabı: Halit Asım ve şiiri üzerine bir inceleme
}

\section{Mustafa KARADENIZ}

APA: Karadeniz, M. (2021). Karanlık bir ruhun ıstırabı: Halit Asım ve şiiri üzerine bir inceleme. RumeliDE Dil ve Edebiyat Araştırmaları Dergisi, (24), 631-646. DOI: 10.2900o/rumelide.995389.

\section{$\ddot{O} \mathbf{z}$}

Bu çalışma Cumhuriyet Dönemi Türk şiirinin gölgede kalmış şairlerinden biri olan Halit Asım’ın yaşamını ve şiirini hastalık, ölüm korkusu ve melankoli kavramları ışı̆̆ında incelemeyi amaçlamaktadır. Bu inceleme yoluyla Asım'ın hayatıyla şiirleri arasındaki paralelliğin düzeyi serimlenir. 1918 yılında Burdur'da doğan şair, kronik kalp hastalığı sebebiyle henüz yirmi üç yaşındayken hayatını kaybeder. Ömür adıyla kitaplaştırılan şiir ve mektupları, şairin hastalığının ve melankolik mizacının güdümündedir. Sekiz yaşındayken yakalandığı kalp hastalığı, Asım'ın ölüm kavramıyla yaşamının çok erken bir evresinde tanışmasına sebep olur. Hastalı̆̆ı ve bundan ileri gelen ölüm korkusu, onun hayatını ve şiirlerini şekillendiren başlıca etken olur. Bu korku, kimi şiirlerde yoğunlaşarak vehme dönüşür. Hüzün, korku ve vehim duygularının süreğen karakteri, Asım'ın şiirlerini melankoli kavramı ışı̆̆ında okumaya imkân verir. Ancak melankolik durumun Asım'da iki farklı evreye ve karaktere sahip olduğu dikkat çeker. İlk evre, şairin kötümser ruh hâlini anlamlandırmaya çalışması şeklinde belirir. İlk evrenin bir "kayıp nesne" ekseninde şekillenmesi, melankoli olgusunun doğasıyla paralellik gösterir. İkinci evre ise ölüm düşüncesi etrafında gelişen duygu ve düşüncelere odaklanır. Dolayısıyla Asım'ın yaşadığı melankolik durum, mizacından ve ölüm düşüncesinden beslenir. Bu çerçevede, yaşamını kuşatan melankoliyle başa çıkmak için Asım'ın birtakım telafi arayışlarına girdiği söylenebilir. Mektuplarında ve şiirlerinde başka diyarlara özlem duyma, kaçma isteği, karşı cinsle münasebetler ve istikrarlı dostluk ilişkileri bu telafi çabasını yansıtan başlıca durumlar olarak öne çıkar. Kaynağını yaşamından alan şiirlerinin içerdiği kasvet ve yoğun imgesellik, Halit Asım'ı Türk şiirinin özgün ve sıra dışı şairlerinden biri olarak değerlendirmeye imkân verir.

Anahtar kelimeler: Halit Asım, Ömür, hastalık, ölüm, melankoli

\section{The suffering of a dark soul: A study on Halit Asım and his poetry}

\begin{abstract}
This study aims to examine the life and poetry of Halit Asım, one of the poets of Turkish poetry in the Republican Period, in the light of the concepts of illness, fear of death and melancholy. Through this analysis, the level of parallelism between Asım's life and his poems is revealed. Born in Burdur in 1918, the poet dies at the age of 23 due to chronic heart disease. His poems and letters, published as a book called Ömür, are guided by the illness and melancholic temperament of the poet. The heart disease he caught at the age of eight causes Asim to meet the concept of death at a very early stage in his life. His illness and the resulting fear of death are the main factors shaping his life and poetry. This fear turns into a delusion in some poems. The chronic character of sadness, fear and delusion makes it possible to read Asım's poems in the light of the concept of melancholy. However, it is noteworthy that the melancholic situation has two different phases and characters in Asim. The first
\end{abstract}

Dr. Öğr. Üyesi, Batman Üniversitesi, Fen-Edebiyat Fakültesi, Türk Dili ve Edebiyatı Bölümü, Yeni Türk Edebiyatı ABD (Batman, Türkiye), gulderim@hotmail.com, ORCID ID: 0000-0002-4833-0207 [Araştırma makalesi, Makale kaylt tarihi: 05.08.2021-kabul tarihi: 20.09.2021; DOI: 10.29000/rumelide.995389]

Adres | Address

RumeliDE Dil ve Edebiyat Araştırmaları Dergisi $\quad$ RumeliDE Journal of Language and Literature Studies Osmanağa Mahallesi, Mürver Çiçeği Sokak, No:14/8 $\quad$ Osmanağa Mahallesi, Mürver Çiçeği Sokak, No:14/8 Kadıköy - ÍSTANBUL / TÜRKIYE 34714 Kadıköy - ISTANBUL / TURKEY 34714 e-posta: editor@rumelide.com e-mail: editor@rumelide.com, tel: +90 505 7958124, +90 2167730616 phone: +90 505 7958124, +90 2167730616 
phase appears as poet tries to make sense of his pessimistic mood. The formation of the first phase on the axis of a "lost object" shows parallelism with the nature of the phenomenon of melancholy. The second phase focuses on the feelings and thoughts that develop around the idea of death. Therefore, the melancholic situation that Asım experiences is fed by his temperament and the thought of death. In this context, it can be said that Asım is seeking some compensation in order to cope with the melancholy that surrounds his life. In his letters and poems, the longing for other lands, the desire to escape, relations with the opposite sex and stable friendships stand out as the main situations that reflect this compensation effort. The gloom and intense imagination in his poems, which take their source from his life, make it possible to evaluate Halit Asım as one of the original and extraordinary poets of Turkish poetry.

Keywords: Halit Asım, Ömür, illness, death, melancholy

\section{Giriş}

Halit Asım, Cumhuriyet Dönemi Türk şiirinin gölgede kalmış şairlerinden biridir. Tam adı Halit Asım Demirsoy olan şair 1918 yılında Burdur'da doğar. Burdur, Adana ve Antalya'daki ilk ve orta öğreniminin ardından Antalya lisesinin ikinci sınıfındayken sağllk sorunları sebebiyle okulu bırakmak zorunda kalır. Nitekim bu hastalığa bağlı olarak aort kapakçı̆̆ı yetmezliği sebebiyle henüz yirmi üç yaşındayken tedavi için gittiği İstanbul'da hayatını kaybeder. Asım'ın yaşamı, ailesi ve yakın çevresi hakkındaki bilgiler oldukça sınırlıdır. Bu konuda bilgi edinilebilecek en sağlam ve birincil kaynak, yakın dostu Niyazi Tunga'ya yazdığı mektuplardır. Bu mektuplarda da aile efradına ve ahvaline dair bilgiler çok sınırlı bir düzeydedir. Babasının edebiyat öğretmeni olduğu, annesinin vefat ettiği, bir kardeşle bir ablanın varlığ gibi hususlar muhtelif mektuplarda sadece küçük birer anekdot olarak geçer. Sekiz yaşında yakalandığı "adali romatizma”nın yol açtığı kronik kalp hastalığı, Halit Asım’ın yirmi üç yıllık yaşamının seyrini bütünüyle şekillendirir. İkinci Dünya Savaşı’ndan sonra basit bir ameliyatla tedavi edilebilecek bu rahatsızlık, içe dönük karakteriyle de birleşince Asım'ın edebî uğraşının tonunu ve rengini belirler. Yakın tarihte bir araya getirilen şiir ve mektuplarında bu hastalığın ve şairin hassas bir duyarlığa sahip oluşunun örtük ve açık etkilerini enikonu izlemek mümkündür.

Hakkında yazılan birkaç kısa yazının ortak noktası, Halit Asım'ın "sükût suikasti”ne uğramış bir şair olduğu yönündedir. "Bu Bir Sahip Çıkış Yazısıdır" başlıklı yazıda Orhan Kahyaoğlu, yakın tarihli bir iki antoloji haricinde gerek Asım'ın gerekse şiirlerinin kararlı bir şekilde görmezden gelindiğini belirtir (1995: 61). Murat Batmankaya ise bir talihsizlik olarak nitelediği bu görmezden gelinmenin, Asım'ın kanon dışında gelişen şiir tarzından kaynaklandı̆̆ını öne sürer. Batmankaya’ya göre söz terazisi çok hassas bir şair olan Asım, genç yaşına rağmen yazdığı olgun şiirlerle "çitin ötesine bakmaya cüret eden şiirler" (1999: 30) yazar. Yaşamına dair alınyazısının şiirlerine de sirayet ettiğini söyleyen Arif Damar, Türk şiirinin topyekûn toplumsallığa kaydığı, Ahmet Hamdi Tanpınar, Ahmet Muhip Dıranas, Ahmet Haşim ve Yahya Kemal gibi ikon şairlerin bile gölgede kaldığı bir dönemde, Asım'ın da yazınsal yazgısının anlaşılmamak, unutulmak olduğunu belirtir (Damar, 1989: 17). Asım’ın bir "vehim şiiri” yazdığına dikkat çeken Kemal Durmaz ise, bu görmezden gelinmeye ilişkin olarak malumat eksikliğine işaret eder: "Bugün Halit Asım hakkında kabaca, 1918 yllında Burdur'da doğduğunu, Antalya'da ikinci sınıfa kadar liseyi okuduğunu, 1940 yllında şiir kitabı yayımladığını ve 1941'de de öldüğünü biliyoruz sadece" (Durmaz, 1989: 7).

Antalya'da arkadaşlarıyla birlikte çıkardıkları Çağlayan'ın yanı sıra Hamle ve Varlık gibi dergilerde yayımlanan şiirlerinde Halit Asım, Halit Çalköy, Nazmi Sezai, Mehmet Elsazı ve Celâl Sumer imzalarını

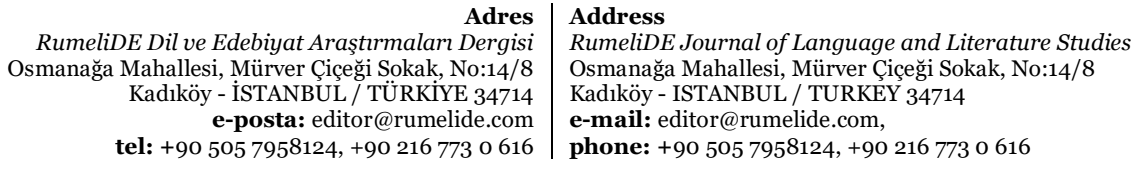


kullanan şairin tek şiir kitabı olan Ömür, ölümünden bir yıl önce 1940’ta yayımlanır. Hakkında yazılanlara bakıldığında kısa ömrüne ve uğradığı "sükût suikasti”ne karşın Halit Asım’ın özgün bir şair olduğu söylenebilir. Orhan Kahyaoğlu'na göre içe dönük ve ruhsal tarzdaki şiirlerinde yarattı̆̆ı imge ă̆ıyla Asım benzersiz bir şairdir. Yaşadığı dönemde görünürlük kazanamamış olmasının temel sebebi de bu çizgi dışı tarzıdır. Kahyaoğlu, şüphe ve vehmin yörüngesinde seyreden şiirleriyle Asım'ın kasvetli ve "gecegil" bir dünya kurduğunu belirtir. Mistik bir algıy gözeten şiirleri, Fazıl Hüsnü Dağlarca'nın 1940 öncesi ve sonrası şiirlerinden izler taşısa da biraz eşelendiğinde, Asım’ın vehmiyle, doğaya yaklaşımıyla, iç dünyasına hâkim olan karamsar atmosferle ve varoluşsal arayışlarıyla farklı bir şiir kurmaya çalıştı̆̆ hemen görülecektir. Dönemin toplumcu gerçekçi ve Garip çizgisindeki şiirleriyle kıyaslandığında Asım'ın çok farklı ve naif bir şiir yazdı̆̆ı söylenebilir (1995: 61).

Asım'ın bir vehim şiiri yazdığı konusunda ortak bir kanı bulunmaktadır. Kahyaoğlu (1995: 63), Asım'ın şiirlerindeki bu özelliğin Yahya Kemal ve Necip Fazıl'dan daha yoğun olduğunu, yaşasa ve yazmaya devam edebilmiş olsa, bunun kısa sürede çok daha iyi anlaşılabileceğini belirtir. Benzer şekilde Kemal Durmaz da Asım'ın şiirlerinin temel karakteristiğinin vehim olduğunu, bu tarzın en yoğun ve güzel ifadesini Cumhuriyet Dönemi'nde Asım'da bulduğunu ifade eder (1989: 7). Toplumcu sanat anlayışı ve Garip çizgisinde şiirler yazmanın geçer akçe olduğu zamanlarda alabildiğine bireysel ve kasvetli bir şiir tarzını sürdürmek, Asım'ın görmezden gelinmesini perçinler. Garip şiirinin tozu dumana kattığı günlerde yayımlanan Ömür de Asım'ın yazgısından nasibini alır. Hayatının zavallı emeği olarak nitelediği ve "benden daha acılıdır" (Asım, 2015: 135) dediği Ömür hakkıyla değerlendirilemeden unutulur, gider.

Yaşamı ve ölümüne yol açan hastalığı şiirlerini şekillendiren başlıca amiller olmakla beraber, Halit Asım'ın dönemin sanat ve edebiyat ortamını yakından takip ettiğini belirtmek gerekir. Hakkında yazılanlar, şairin Türk ve dünya edebiyatlarının önemli isimlerinden etkilendiğini işaret eder. Söz gelimi Arif Damar, Asım'ın yazınsal kültür ve bilgisinin o dönemin kalburüstü şairlerinden hiç de aşağı kalmadığını, Baudelaire'in Elem Çiçekleri’ni elinden düşürmediğini, Mallerme'yi, Necip Fazıl'ı, Fazıl Hüsnü Dağlarca’yı, Ahmet Haşim’i iyi okuduğunu söyler (2006: 44). Bu konudaki en sağlam kaynağın, şairin terekesinden çıkan mektuplar olduğu söylenebilir. Yakın dostu ve sırdaşı Niyazi Tunga'ya Ağustos 1936 ile Haziran 1941 tarihleri arasında yazdığı 45 mektupta, Asım’ın özellikle etkilendiği yazar ve şairleri tespit etmek mümkün. Bu bağlamda Necip Fazll'ın Bir Adam Yaratmak oyununun ana karakteri Hüsrev, Asım için âdeta bir rol modeldir. Bu yoğun etki, birden çok mektupta Hüsrev'den söz edilmesinden anlaşlabilir. 16. 02. 1938 tarihli mektupta Asım, bu eserin ve ana karakterinin üzerindeki etkisini şu satırlarla ifade eder:

\begin{abstract}
"Hüsrev beni altüst etti. Ah! Sana binlerce teşekkür dostum. Bana oradan yepyeni bir âlem, [eğ]ilip kendi ruhumun derin uzaklarında görmiye ve bulmıya çalıştığım bir âlem yolladın. Bilsen... Beni şu yaldızlı hayattan biraz daha uzaklaştırmak için önüme koyduğun bu kitabın, ne büyük, ne ölçülemez bir -kaçıp kaybolabilmek ve unutmak- sevinci ile karşılaştı̆̆ını bir bilebilsen... (...) "Bir Adam Yaratmak" $n$ bendeki manevi kıymetinin yanında her mukabelenin pek zavallı ve yetim kalacağını tahmin etmek isteğimi [men etti.]” (Asım, 2015: 83).
\end{abstract}

Asım, Hüsrev'le kendisi arasında bir kader birliği kuracak ölçüde bir özdeşimden söz eder. Bu özdeşim ağı, George Duhamel'in Geceyarısı İtirafı romanının içe dönük ve evhamlı karakteri Salavin'le başlayıp Dostoyevski'nin "yeraltı adamı"na kadar uzanır: "Salavin bize bir gece yarısı kadar karanlık ve mütereddit bir ruhun bütün ıtıraplarını anlatıyor. Düştükleri âlemi yaşadıkları âlemden daha üstün görenlerin en parlak sembolü Salavin'dir. Endişeli ruhunu, tuhaf hareketlerini, muvaffakiyetsizliklerini gördüğümüz 'Salavin' tam manasıyla Dostoyevski’nin anlattığı 'yeraltı adamı'dır” (Asım, 2015: 89). Bunların yanına konumladığı Faust, Werther gibi karakterlerle Abdülhak Hamit Tarhan'ın Makber ön

Adres | Address

RumeliDE Dil ve Edebiyat Araştırmalar Dergisi $\quad$ RumeliDE Journal of Language and Literature Studies

Osmanağa Mahallesi, Mürver Çiçeği Sokak, No:14/8 Osmanağa Mahallesi, Mürver Çiçeği Sokak, No:14/8

Kadıköy - ÍSTANBUL / TÜRKIYE 34714 Kadıköy - ISTANBUL / TURKEY 34714

e-posta: editor@rumelide.com e-mail: editor@rumelide.com,

tel: +90 505 7958124, +90 2167730616 phone: +90 505 7958124, +90 2167730616 
sözündeki muzdarip şair imajı ve Suut Kemalettin’in Büyük Muzdaripler: Schopenhauer, Nietzche, Tolstoy adlı eseri de benzer özelliklere sahiptir. Asım'ın bu trajik karakterle kendi melankolik ve kasvetli yaşamı arasında bir bağ kurduğu çok açıktır. Anatole France'ın epiküryen felsefeden beslenen romanları ise, kapıldığı yoğun karamsarlıktan ve ölüm korkusundan Asım’ı kurtararak yaşama ilişkin ara sıra beliren iyimser tavrın başlıca tutamaklarından biri olur.

Mayasını içe dönük ve hassas kişiliğinden, kısa ömründe sırtında bir kambur gibi taşıdığı hastalığından ve yaşadığı tarihsel dönemden alan şiirleriyle Halit Asım, uzun yıllar görmezden gelinse de, Cumhuriyet Dönemi Türk şiirinin özgün ve kasvetli şairlerinden biridir. Bu çalışma, Halit Asım’ın yaşamını ve şiirini şekillendiren hastalık, ölüm ve melankoli kavramlarını ve bu kavramlara bağlı olarak gelişen kaygı ve korku durumlarını telafi etme çabalarını şiirleri ve mektupları ışığında bir yakın okumaya tabi tutmayı amaçlamaktadır. Bu inceleme yoluyla şiir dünyasını şekillendiren temel kavram ve motifler ortaya konarak Halit Asım'ın hayatıyla şiirleri arasındaki paralelliğin düzeyi serimlenmeye çalışılacaktır.

\title{
1. Hastalık ve ölüm korkusu
}

Marc Wittman, Hissedilen Zaman adlı eserinde, fanilik ve ölüm gibi kavramların normal koşullarda yaşlı insanlar için öncelik kazandığını ancak ciddi bir hastalık gibi sıra dışı durumların, ölüm olgusunu her yaş grubundan insanların daha yakından ve içerden deneyimlemesine sebep olabileceğini belirtir. (2018: 91-92). Henüz sekiz yaşındayken yakalandığı kalp hastalığı, Halit Asım’ın da ölüm kavramıyla yaşamının çok erken bir evresinde tanışmasına sebep olur. Tedavi imkânı olmayan hastalığı ve bundan ileri gelen ölüm korkusu Asım'ın hayatını ve şiirlerini şekillendiren başlıca etken olur. Dostu Niyazi Tunga’ya yazdığı mektuplarda, bu hastalığın ve yol açtığı kaygı ve korkuların seyrini kronolojik olarak takip etmek mümkündür. 45 mektubun ilk on birinde bu hastalıktan ve yol açtığı ölüm korkusundan pek söz edilmez. Daha ziyade karamsar ve mahzun ruh hâline dair duygu ve düşünceler dile getirilir. Ancak 6. 5. 1938 tarihli 12. mektuptan itibaren bu süreğen hastalığın maddi ve manevi etkilerinden, ölüm korkusundan açık ve ayrıntılı bir şekilde söz edilmeye başlanır. Hastalığından kaynaklanan vehim ve korku dolu düşüncelerin yol açtı̆̆ çaresizlik ve bundan menkul öfke artık mektuplara taşmaya başlar:

\begin{abstract}
"Hasta dostun ağlıyor artık Niyazi. Yalnız geçirdiği saatlerini gözyaşlarında yıkıyor. Ölümün korkunç ayak seslerini duyan kardeşinin haline sen de ağla. Gencim... Nasıl korkmıyayım. Nasıl içim kanlarla dolmasın. Ölüm!.. Meğer hayat ne güzelmiş. Razıyım bütün ıztıraplara... görmek, duymak, düşünmek hassalarım yok olmasın. Ölüm korkusu... 19 yaşım... aydınlık yarınlar... Her şey, hepsi... [A]h! Niyazi korkuyorum. Fakat hastayım[,] maddeten hastayım” (Asım, 2015: 94).
\end{abstract}

Takip eden mektuplar da hastalık ve ölüm korkusu etrafında şekillenen duygu ve düşünceler içerir. Emmanuel Levinas, varlığın özünü oluşturan yaşama tutunma çabasının (conatus) ölüm tarafından tehdit edilmesinin, kaygının idaresi altında gelişen duygusallığın kaynağı olduğunu belirtir (2014: 28). 28. 5. 1938 tarihli mektupta, Asım'ın da çok acı çektiği, kaygı ve korku içinde olduğu okunur. Hastalığından ve ölüm korkusundan dostu Niyazi”ye “içi çürüyerek” “dudakları ezilerek" söz eder (Asım, 2015: 95). Bu hastalık tohumunun içinde yeşerttiği ölüm ağacının ince ve sivri dikenleri vehim, kayıp, kaygı, korku, kaçış gibi kavramlara tahvil edilerek Asım’ın şiirlerinin genel ton ve atmosferini şekillendirir.

Ölüm kaygısı, Asım’ın şiirlerinin de en temel motiflerden biridir. Yaklaşan ölümün uyandırdığı kayıp ve hüsran duyguları şiirler aracılı̆̆ıyla da kayıt altına alınır. "Bir Masal" şiirinde anlatıcı özne, ruh hâlinin de etkisiyle ömrünü tükenip bitecek bir masala benzetir. Bu ömrün biyolojik olarak durma noktasına geldiği yerde, herkes gibi kendisinin de bu gerçeği yaşayacağını "ölüm kervanı" somutlamasıyla ifade eder:

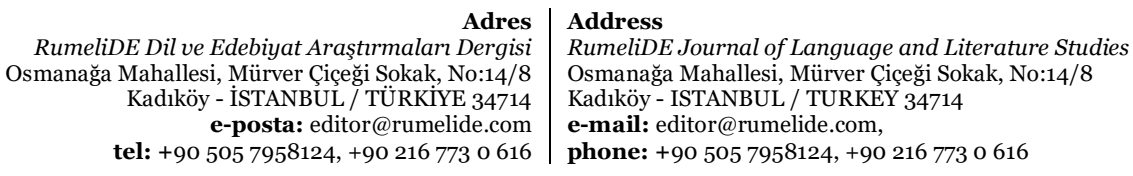


"Bir masal senin ömrün,

Tükenip bittiği gün,

Gölgelerle kalıver...

Donunca sicak kanın,

Bir ölüm kervanının,

Peşine takılıver...” (Asım, 2015: 20)

Ölüm kaygısından ileri gelen huzursuzluk, Asım'ın dış dünyayı alımlama tarzını etkiler. "Hayâl Şehir" şiirinde anlatıcı, içinde bulunduğu ruhsal durumu, bozulmuş bir kuş yuvasına benzetir. Kuşların kanat çırpışları ise bir ölüm duasını andırır. Şiir öznesinin içinde soluk aldığı atmosfer daimi bir karanlığa yazgllıdır. "Bir Masal" şiirinde olduğu gibi bu karanlık yaşam, bedbîn ruhların sığındığı, bir teselli ümidi olan bir hayal şehre hicretle son bulacaktır:

"Bozuldu ruhun yuvası,

Şimdi odur kanat çırpan.

Kuşların ölüm duası,

Bu yakınlarda duyulan.

Ruhların gittiği yere,

Kuruldu bir hayâl şehir.

Yumulan altın gözlere,

Geceden şarkı ve şiir.” (Asım, 2015: 25).

Bu kaygının şairde yarattığı ruh hâli, kimi şiirlerde yoğunlaşarak bir vehme dönüşür. "Uykusuzluğum” şiirinde anlatıcı öznenin içinde bulunduğu ruhsal buhranın etkisiyle dış dünya ve eşyanın algılanma tarzı gerçeklikten kopar. Şiirin anlatıcısı, uykusuzluğun yarattığı algı zayıflığının etkisiyle pencere camında "ölü bir hayâl gör[ür]." Anlatıcının indinde "[g]ece korkulu gözler gibidir" (Asım, 2015: 51). Vehme dönüşen algılama tarzının temel sebebi, hastalık ve ölüm korkusundan ileri gelen ruhsal parçalanmadır: "Görür gibiyim şimdi ruhumda, / Açılan derin uçurumu" (Asım, 2015: 51).

Asım'ın hastalığına ve ölüm korkusuna dair düşüncelerinin sabit bir seyir izlemediği, ruh hâline göre değiştiği söylenebilir. Mektupların genel tonu hüzün ve karamsarlık duygularının yörüngesinde seyretse de yaşama karşı zaman zaman iyimser duyguların da dile getirildiği görülür. 27. 6. 1938 tarihli mektupta, söz gelimi, ölüm hakkında daha önce yazdıklarının ağırlı̆ına ve gerçekliğine işaret etse de bunlara saplanıp kalmamak gerektiğini yazar. Önceleri varlığını titreten ve vehme boğan ölüm fikri artık "hayatın bir anlık saadetine mağlup" (Asım, 2015: 97) olur. Kısa ve fani ömrünü alabildiğine yoğun bir şekilde deneyimlemek, hayattan alacaklı gitmemek düşüncesi şairin şiirlerine de yansır. Bu bağlamda "Ölesiye" şiiri, denizi, kadını ve meyve kokulu sıcak bahçeleri ölesiye yaşamak arzusunu konu edinir. Ancak nispeten olumlu duygular içeren bu şiirde bile ölüm kol gezmektedir. Anlatıcı, sanki ölümden önceki son arzularından söz etmektedir. Dolayısıyla Asım’ın ümit ve sevinç içinde olduğu anların içinde de mutlak bir burukluk ve hüzün vardır.

Nitekim bu iyimser tutum uzun sürmez, küçük bir uyaran veya çağrışımla derhâl üzüntü ve huzursuzluğun girdabına kapılır. Hastalığı ve mizacı, Asım’ın kendisine ve çevresine yönelik pesimist

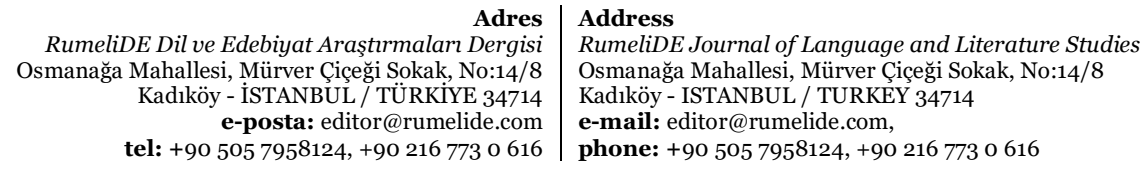


algısını bir alışkanlığa dönüştürür. 25. 11. 1938 tarihli mektup, şairin içinde bulunduğu kısa mutluluk molasının bitmiş olduğunu enikonu işaretler. Gelinen noktada yaşanan sıkıntı ve vehimler, şairin ölümü bir kurtuluş olarak görmesine yol açacak bir yoğunluğa ulaşır: "Artık ölmeliyim... Yağlı iplerde sallanan morarmış ölülerin korkulu rüyasını gören ömrüm bitmeli!.. Bana acı! Ruhuma merhametlikler’in kıvılcımlı hüznü dolsun” (Asım, 2015: 109). Şairin güneşli ve masmavi bir gökyüzünü andıran ruh hâli, karanlık ve kasvetli bir geceyle yer değiştirir. Mektuplarında mükerrer olarak söz ettiği "yeisle iradenin mücadelesi”nde kazanan yeis olur. Yaşadığı ümitsizlik ve çaresizlik adından başlayarak "Bir Avuç Et Yumă̆ı" şiirine çok karanlık imajlarla yansır:

“Örtüp perdelerini şuurun,

Saklayın orda bir avuç eti.

Ve gözlerine kilitler vurun,

Görmesin Allah’ı ve Cenneti.

Bu kalın kapıların ardında,

$\mathrm{O}$ artık hayatı düşünmesin.

Bir ses desin ki daima ona:

-Kat kat dünyaların altına in” (Asım, 2015: 55).

Fiziksel ve ruhsal zorlanma, bilincini felce uğratarak Asım'ı âdeta et yı̆̆ınından ibaret bir varlık derekesine düşürür. Anlatıcının varlığından yabancı bir et parçası olarak söz etmesi, bir irade kaybına işaret eder. Yaşama iradesinin yitirildiği noktada, karamsarlık iç dünyasına bütünüyle egemen olarak anlatıcıyı karanlık sularına çeker. Bu duygu ve düşünce durumu, hastalığının vücudunda bariz etkiler bırakmaya başlamasıyla giderek hâkim bir konuma yerleşir. 1 Mart 1939 tarihli mektupta "artık bir kuru dal gibi kalan vücudu[nun] bozuk yüreğini son günleri[n]in tatlı selamı olarak” (Asım, 2015: 114) dostuna yolluyordur. 25 Mayıs 1940 tarihli mektupta Asım, artık fiziksel olarak tükenme noktasına gelmiştir ve sefalet içinde bir odada ölümü soluyordur. Kendisini hür bir ölü, yaşadığı mekânı da kötü bir mezar olarak görmektedir:

"Sefalet çektiğim odamda ölümü teneffüs ediyorum. Ağır, rutubetli bir koku, böcekler, toz, toprak, pire, alçak bir tavan... Evet, kötü bir mezar ve ben kısmen hür bir ölü... Dünya yüzüne çıkabiliyorum. Zayıfladım ve uzun yüzümle çirkin bir mumya oldum. 1.70 boyuma rağmen 50 kiloyum.. Bu feci çöküş, bu deriden, kemikten ve sinirden ibaret kalışa canım sıkılıyor... (...) Her geçen gün ağır bir yumruk gibi göğsüme iniyor.” (Asım, 2015: 129).

Pasajdaki tasvirlerden fiziksel ve ruhsal bakımlardan feci bir çöküş yaşadığı anlaşılan şair, son mektuplarından birinde dostuna "Kuşlar" adlı şiirini yazarken ikinci bir kriz geçirdiğini aktarır. Nurullah Ataç’a adanan şiir, şairin yaşadığı acılı hayattan gönüllü bir feragat arzusunda olduğunu ima eder. Kasvet ve vehimle dolu bir yaşantı karşısında kurtuluş ümidi, kuşlar ve çocuklarla birlikte firar ederek baharı muştulayan cenubu arayıştadır. Söz konusu mektupla aynı ton ve duyarlığı taşıyan şiirin son kıtası, bu söylenenleri özetleyebilir: "Kuşlar, bu oda kasvetlidir, / Ve insan firar edebilir / Yuvalarda cenubu arayan bir çocukla.” (Asım, 2015: 57).

Emmanuel Levinas, insanda yol açtığı kaygının temelinde ölümün bir anlam fazlalığı mı yoksa eksikliği mi olduğu sorusunun bulunduğunu söyler (2014: 45). Levinas'ın bu tespiti ışı̆̆ında değerlendirildiğinde Asım'daki kaygının temel sebeplerinden biri, ölüm sonrasının sır dolu bir bilinmezlik olarak düşünülmesidir. "Son Günüm İçin" şiirinde bu kaygının ölüm sonrasının bir "sır dolu ülke" olarak

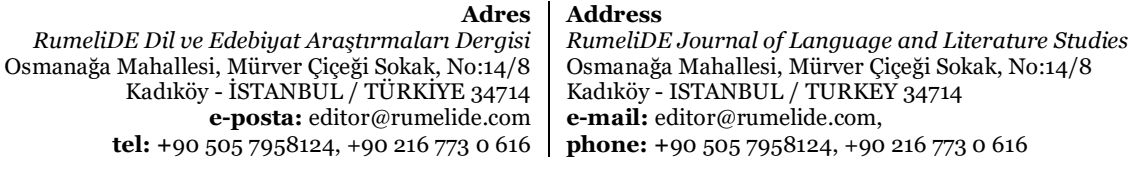


görülmesinden kaynaklandığı anlaşılır. Dolayısıyla Asım'ın ölüm kaygısı, temel motivasyonunu bu anlam eksikliğinden almaktadır:

\author{
"Başladı gene düğün \\ Gidiyorlar ölümün \\ Sir dolu ülkesine \\ Geldiyse eğer o gün \\ Beni alıp götürün \\ Ölümün ötesine” (Asım, 2015: 54).
}

Ölüm fikrinin artık iyice kanıksandığı için söz konusu edilmediği Haziran 1941 tarihli mektuptan birkaç gün sonra Halit Asım hayatını kaybeder. Mektubun içeriği, ilginç şekilde, gündelik yaşamın sıradan akışını yansıtan bir tona ve üsluba sahiptir. Asım, dostu Niyazi'yle yarın buluşacak olmanın heyecanı ve sevinci içindedir. Arif Damar, "Beni yalnız bırakmamıya çalış! Olmaz [mı] Niyazi?" (Asım, 2015: 140) şeklinde sona eren mektubun Asım’ın son sözleri olduğunu ve birkaç gün sonra öleceğini, Feriköy mezarlı̆̆ına gömüleceğini belirtir (1989: 14).

\title{
2. Sairin ethosu olarak melankoli
}

Hastalık ve ölüm düşüncesi Halit Asım'da hüzün, acı ve vehim duygularını süreğen bir duruma getirir. Melankoli kavramıyla örtüşen bu duyguların yoğunluğu ve sürekliliği, Asım'ın şiirlerinin ve mektuplarının temel ethosunu/karakterini yansıtır. Bu durum, Asım'ın şiirlerini melankoli kavramı bağlamında değerlendirmeye imkân verir.

Kelime anlamı "kara safra" olan melankoli, yaklaşık 2500 ylllı geçmişe sahip olan bir kavramdır. İlkin Hipokrat'ın uzun süreli kaygı ve üzüntü durumlarını karşlamak için kullandığı kavram, Aristoteles tarafından dehanın, istisnai bir kişiliğe sahip olmanın alameti olarak değerlendirilir. Hipokrat'ın aksine Aristoteles, melankolinin bir hastalık değil, felsefecinin doğasına özgü bir gerçeklik olduğunu söyler (Kristeva, 2009: 15). Melankolinin Anatomisi isimli eserinde Richard Burton, melankoliyi bir eğilim ve alışkanlık olarak değerlendirerek kavramı daha normal ve insani bir düzeye yerleştirir. Burton'a göre melankoli, insan hayatının belli bir döneminde yaşanabilecek, bariz bir belirtisi olmayan, çoğunlukla korku ve keder duygularının eşlik ettiği bir durumdur (Burton, 2018: 99-100).

Halit Asım’ın yaşamı ve şiirleriyle melankoli kavramının içerimleri arasında bariz bir yakınlık olduğu söylenebilir. Ancak melankolik durumun Asım'da iki farklı evreye ve karaktere sahip olduğu dikkat çeker. İlk evre, Asım'ın kötümser ruh hâlini anlamlandırmaya çalışması şeklinde belirir. İlk evrenin bir "kayıp nesne" ekseninde şekillenmesi, melankoli olgusunun doğasıyla paralellik gösterir. Çünkü "[k]ayıp nesne olgusu melankolinin temel dinamiğidir" (Korkmaz, 2018: 33). İkinci evre ise ölüm düşüncesi etrafında gelişen duygu ve düşüncelere odaklanır. Dolayısıyla Asım'ın yaşadığı melankolik durum, mizacından ve ölüm düşüncesinden beslenir. Bir kayıp nesne ya da anlam arayışıyla başlayan süreç, aradığını hastalıktan menkul ölüm düşüncesinde bulur. Kayıp nesnenin bulunmasından sonra ise melankolinin yol açtığı ruhsal basıncı azaltmak için şairin birtakım telafi çabalarına giriştiği görülür. Asım'ın yaşamını ve şiirini kuşatan bu durumu makul bir şekilde serimleyebilmek için Sigmund Freud'un kavramla ilgili düşüncelerine başvurmak yararlı olabilir.

Yas ve Melankoli adlı eserinde Freud, melankolinin doğasını yas olgusuyla karşılaştırarak yorumlar. Yas olgusunu insan için olağan ve gerekli bir durum olarak niteleyen Freud'a göre "melankoli ise ruhsal

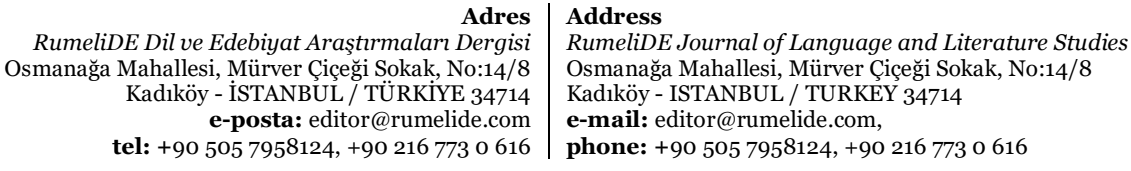


olarak, derin biçimde acı veren üzüntü, dış dünyaya duyulan ilginin sekteye uğraması, sevme yetisinin kaybı, tüm etkinliklere ket vurulması, yerini kendini suçlama ve aşă̆ılamaya bırakmış, cezalandırılacağına dair sanrısal bir bekleyiş içinde kendilik duygusunun değerden düşmesi ile tanımlanır" (Freud, 2014: 19). Yasta kaybın nesnesi belliyken melankolide belirsizdir. Bu müphemiyet, melankolinin süreğen karakterini oluşturur. Dolayısıyla melankoli, nesne yitimiyle ilgili bir ketlenme durumudur. Bu ketlenmenin yol açtı̆̆ en bariz durum, "[b]en duygusunun aşırı derecede azalması ve yoksullaşması[dır]" (Freud, 2014: 22). Dış dünyanın anlam kaybına uğradığı yas durumunun aksine melankolide "ben"in anlam kaybına uğraması söz konusudur. "Hasta kendi 'Ben'ini bize değersiz, beceriksiz ve ahlaki açıdan alçalmış olarak sunar, kendini eleştirir, aşağılar, kovulmayı ve cezalandırılmayı bekler" (Freud, 2014: 22).

Halit Asım'ın erken tarihli mektuplarına yansıyan melankolik ruh hâli Freud'un işaret ettiği bu belirsizlikten kaynaklanır gibidir. Çünkü Asım'ın kendisi de içinde bulunduğu sürekli kaygı hâlini bir türlü anlamlandıramaz. Hastalığından kaynaklı olduğu düşünülse de Asım, bundan hiç söz etmez. Yazdıklarından daha derin ve metafizik bir buhran içinde bulunduğu anlaşılır. 31. 1. 1938 tarihli mektupta yaşadığı ruhsal buhranın nedenlerine dair sorgulamalar, devamlı tekinsiz bir belirsizliğe saplanıp kalır. Makul bir gerekçeye dayandırılamaz. Dahası Freud'un işaret ettiği türden melankolik bir benlik kaybını işaretler:

"Benliğimi örten yığınlar altında, nefessizlikten boğulacağım sanıyorum. Çocuk gibi ağladığım anlar oluyor, oturup yazıyorum olmuyor, okuyorum olmuyor, çıkıp geziyorum olmuyor. İçimi sıkan, nefesimi tıkayan gizli ellerin esiri gibiyim. (...) Nedir? Neden böyleyim, içine gömüldüğüm bu ruh haleti bana hangi meçhul membalardan geliyor? Ruhumu sıkan sebepleri bulmak istiyorum. Ne gezer... Şu mu? Değil. Bu mu? Değil. Hiç, hiçbiri değil. Ya ne?” (Asım, 2015: 81-82).

“Meçhul membalardan” gelerek Asım’ın ruhunu sıkan bu sıkıntının kaynağına ulaşma çabaları takip eden mektuplarda da devam eder. Yaklaşık bir ay sonraki mektubunda, dostu Niyazi Tunga'ya bu vehim ve hüzün hâlini bir türlü tam olarak anlatamamaktan yakınır:

"Anlatamıyorum Niyazi; her gece tanrıma yalvarırım, beni yok etsin diye... Yok olamamak azabını düşün dostum... Düşün onu. Bu benim için hayatı çılgınca seven bir insanın yarın öleceğini bilmesinden daha mahvedicidir. Fakat şu anda, sana, duyduklarımı, uzun zamandır içimde burkulduğum haleti ruhiyeyi ‘tam' olarak anlatamayışım beni öldürüyor. Sana içimdeki kıyameti anlatabilmek benim için muazzam bir saadet olurdu. Anlatamıyorum Niyazi... Bu anlatılamaz" (Asım, 2015: 86).

Yaşadığı ruhsal karmaşayı bir “kıyamet”e benzeten şair, sahip olduğu koşullar göz önüne alındığında mutlu olması gerektiğini düşünür. Bedbin ve küskün oluşuna dair somut gerekçeler arar. Ancak tatmin edici bir cevap bulamaz. İçine gömüldüğü vehim dünyasından kurtulmak için uzun bir mücadeleye girişmesi gerektiğinin farkındadır: "Yeisle irademin mücadelesi uzun sürecek!..” (Asım, 2015: 87). Fakat varlığını bu hâletiruhiyeden kurtaracak irade kuvvetine sahip olup olmadığından emin değildir.

Melankolik hâlin bir tezahürü olan "ben"in kendini değersiz, ahlaki açıdan düşkün ve bu yüzden cezaya müstehak görme eğilimi, Asım'da da görülür. "[B]ir paçavranın tozlu ve kirli ömrüne benzeyen” yaşamının baharında "delik deşik edilmiş bir nişan tahtası gibi, kendi[sin]i köşelere atılmaya müstehak bulu[r]” (Asım, 2015: 93). 27. 6. 1938 tarihli mektupta ben duygusunun enikonu zayıfladığı anlaşılır. Asım kendisini zavallı ve mağlup bir malihülyalar adamı, korkunç bir hiçlik olarak görür: "Zavallı malihülyalar adamı ben. (...) Ben bir hiçim; korkunç bir hiçlik... Hareket, fikir, enerji mayası kalmamış beyniyle bir hiçlik[,] kabuk bağlamış iradesiyle bir hiçlik" (Asım, 2015: 97).

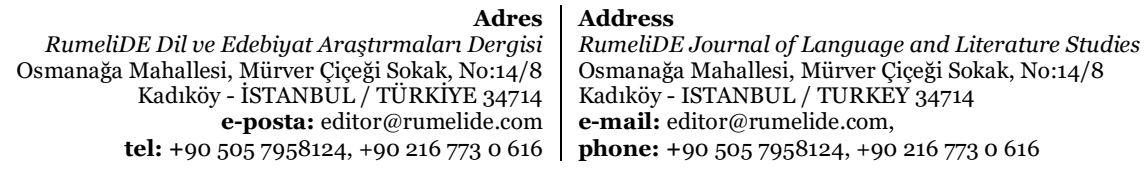


Melankolik hâlin ayırt edici özelliklerinden biri, kişinin sebepsiz bir duygu karmaşası yaşamasıdır. "Melankolik mizaçlı insanlar bir günlük zaman dilimi içinde bile, kimi zaman hüzünlü, kimi zaman heyecanlı olabilirler" (Teber, 2013: 104). Asım'da da benzer ruhsal ve duygusal savrulmalar izlenir. Bazen, iyimser satırların hemen akabinde sebepsiz bir hüzne, âdeta vehme yuvarlandığı görülür. Asım'ın kendisi de bu durumun farkındadır. Antalya'dan dostuna şöyle seslenir: "Beni, bir sarhoşu dinler gibi dinle Niyazi. Yemin ederim ki ne söylediğimi bilmiyorum. Yalnız içimde bir kıyamet var. Dinlediğin bu birbirini tutmaz sesler, o kıyametten kopan namütenahî feryatların bu sayfalara aksedenidir. İçim dolu Niyazi. Beni çatlatıp paramparça edebilecek bir volkan taşıyorum içimde" (Asım, 2015: 98). Sevinçkeder, mutluluk-hüzün gibi tezat duygular yaşamın doğal seyri içinde bir arada var olsa da Asım'da ibrenin hemen her zaman keder ve hüzünden yana olduğu söylenebilir. Burton'un sözlerini uyarlayarak söylemek gerekirse, Asım'ın kahkahasının tam orta yerinde daimi bir keder bulunmaktadır (Burton, 2018: 101). Yaşadığı nadir esenlik anlarını, şair oluşunun etkisiyle şu ilginç ve çarpıcı benzetme üzerinden dile getirir: "Neşem bir zenci kadının koca suratını beyaza çevirmek için süründüğü pudradan farksızdır" (Asım, 2015: 109). Asım'ın beyhude bir makyaja benzetilen bu kısa mutluluk anlarının ardında büyük ve kapkara bir hüzün bulunmaktadır. Kaan Arslanoğlu çocukluğundan itibaren yaşama karşı olumsuz koşullanan böyle kişilerin depresif ya da disforik mizaçlı bir kişiliğe sahip olduklarını belirtir: "Böylesi kişilikler işleri, koşulları yolunda gittiğinde görece, mutlu olabilirler, ancak koşullar az buçuk dönmeyegörsün, çabucak karamsarlı̆̆a düşerler ve sıklıkla depresyona girerler. Bazıları için yaşam arada kısa mutluluk molaları verilen uzun bir depresyon gibidir” (Arslanoğlu, 2007: 97).

$\mathrm{Bu}$ anlamlandırılamayan hüzün, aradığı gerekçeyi ölüm düşüncesinde bulur. Kitaptaki 12. Mektupla birlikte Asım'ın melankolik ruh hâlinin temel sebebi ölüm kavramına bağlanır. Yaşamsal ve nesnesi belli bir kaygı durumu karşısında belirsiz duygular aradığı mecraya kavuşur. 6. 5. 1938 tarihli mektuptan anlaşıldığına göre birden beliren ölüm düşüncesi, Asım'da büyük bir korkuya sebepolur:

\begin{abstract}
"Hasta dostun ağlıyor artık Niyazi. Yalnız geçirdiği saatlerini gözyaşlarında yıkıyor. Ölümün korkunç ayak seslerini duyan kardeşinin haline sen de ağla. Gencim... Nasıl korkmıyayım. Nasıl içim kanlarla dolmasın. Ölüm!.. Meğer hayat ne güzelmiş. Razıyım bütün ıztıraplara... görmek, duymak, düşünmek hassalarım yok olmasın. Ölüm korkusu... 19 yaşım... aydınlık yarınlar... Her şey, hepsi... [A]h! Niyazi korkuyorum. Fakat hastayım[,] maddeten hastayım" (Asım, 2015: 94).
\end{abstract}

Ölüm düşüncesiyle ilk temasın yarattığı şok durumundan sonra, Asım’ın melankolik mizacının artık bu korkunun idaresinde geliştiği söylenebilir. Anlamlandırılamayan marazi duygu ve düşünceler artık ölümle ilişkili imgeler üzerinden dile getirilir. Asım'ın ruh hâline hakim olan kasvet, muhayyilesini de şekillendirir. Asım'ın solgun dünyasında limanlar ışıksız, bindiği gemiler kara, dalgalar mezar, saatler korkulu, kuşlar çürümüştür. Her şey “sona ermeye” yazgılıdır. "Son” adlı şiir, ölüm düşüncesinin idaresi altında gelişen bu yoğun kasveti örneklemek için işaret edilebilecek şiirlerden sadece biridir:

\footnotetext{
"Kapadı bulanık bir sükût,

Nedametle susan bir anı.

Uzak düştü kalpte son hudut,

Tükendi hayâlimin kanı.

Ve hikâyesi erdi sona,

Nefesi kesilen rüyamın.

Uçtu dalların sükûnuna,

Kuşları çürümüş dünyamın.” (Asım, 2015: 19).
}

Address

RumeliDE Journal of Language and Literature Studies Osmanağa Mahallesi, Mürver Çiçeği Sokak, No:14/8 Kadıköy - ISTANBUL / TURKEY 34714 e-mail: editor@rumelide.com, phone: +90 $5057958124,+902167730616$ 
Takip eden mektupta hastalık ve ölüm düşüncesinin çocukluğundan itibaren bütün yaşamını şekillendirdiğini Asım doğrudan dile getirir. Melankolinin bir nesneye, kaynağa bağlanması, sadece sonrasını değil, Asım’ı ölüm düşüncesinden önceki yaşantısını da anlamlandırmasına zemin hazırlar:

\begin{abstract}
"Ben hasta bünyeli bir insanım Niyazi. Kalbim yaşımla mukayese edilemeyecek kadar zayıf. Sekiz yaşımda tutulduğum 'Adalî Romatizma'nın genç yaşıma bıraktığı hediye müzmin bir 'kalp hastalığı' oldu. Hastayım. Ve çok iyi biliyorum ki fena, cidden fena hastayım. Hepsi, bir böcek gibi kabuğu içine çekildiğim bedbinî düşünceler, 'burdan ötesi'nin çare oluşu, fildişi kulelerin müphem ümitleri ve yarı açılan kapıları, tereddüt, kısır neticelere gebe kararlar, hepsi, [her şey] bu hastalığın içime attığı tohumdan çıkan dalların ince ve sivri dikenleridir” (Asım, 2015: 95-96).
\end{abstract}

Demek "bir böcek gibi" kendi kabuğuna çekilmesine sebep olan düşünceler, yaşanan tereddütler, kısır neticelere gebe kararların tümü, bu hastalığın Asım'ın içinde yeşerttiği ölüm ağacının ince ve sivri dikenlerinden kaynaklanmaktadır. Kaynağını ölüm kavramında bulduktan sonra, bütün yaşantısını kuşatan melankoliyle başa çıkmak için Asım'ın birtakım telafi ve çözüm arayışlarına girdiği söylenebilir. Gerek mektuplarında gerekse şiirlerinde başka diyarlara özlem duyma, kaçma isteği, Asım'ın yaşadığı melankoliyi bir nebze de olsa seyreltme isteğinden kaynaklanır.

\title{
3. "O Belde"ye hicret ya da firar
}

Süreğen bir karaktere sahip melankoliyle baş edebilmek için HalitAsım'ın başvurduğu temel stratejilerden biri, bulunduğu ortamdan kaçip kurtulmak, başka mekânlara sığınmaktır. Asım, içinde bulunduğu ve ağırlığını her geçen gün daha fazla hissettiği “vehim dünyası”ndan kurtulmak için sürekli bir arayış ve sorgulama içerisine girer. 23-24. 2. 1938 tarihli mektubunda Asım, kendisini yaşadığı kasvet ve karanlıktan kurtarıp aydınlığın ötesine götürecek iradenin nerede olduğunu sorar (Asım, 2015: 87). Bu iradenin şiirlerde muhtelif imgeler üzerinden görünürlük kazandığı söylenebilir. Söz gelimi "Resimdeki Bahar" şiirinde uzak iklimlere duyulan hasrettir (Asım, 2015: 16). "Bir Ses" şiirinde bu irade hayalin dalı üstündedir (Asım, 2015: 17). "Orman" şiirinde ise anlatıcı öznenin gözlerini emziren limandır. Muhtelif görünümlere sahip bu iradenin temel amacı, içinde bulunduğu vehim dünyasından kaçarak arzulanan huzur ve mutluluk mekânına varmaktır. Hâlihazırdaki bir örnek yaşantının tahammül edilemez bir kıyamete dönüştüğü noktada, hicret kaçınılmazdır: "Hep aynı bahçedesin, durmadan bahçevanlık, / Hatıra ve kıyamet yığınına tahammül; / Hicret! Lâkin yollarda izler yakın, tanıdık...” (Asim, 2015: 40).

Bu hicretin temel amacı arzulanan, hayali kurulan yaşama ulaşmaktır. “Üç Arkadaş” şiirinde çocukların gözlerine yansıyan bu hayal uzakta olsa da anlatıcının bu konuda kararlı olduğu görülür. Kasvet sona erecek, biteviye süren "kızl yangınların humması"ndan (Asım, 2015: 83) kurtulunacaksa, hicret bir firara da dönüşebilir. Bu firarda, anlatıcıya eşlik eden yol arkadaşları kuşlar ve çocuklardır. Çünkü biri özgürlüğü, diğeri ise saflığı ve katıksız yaşama sevincini temsil etmektedir:

"Kuşlar, insan firar edebilir,

Yuvalarda cenubu arayan bir çocukla;

Ve kaçabilir bir dizi mavi boncukla.

(...)

Kuşlar, bu oda kasvetlidir,

Ve insan firar edebilir

Yuvalarda cenubu arayan bir çocukla...” (Asım, 2015: 57).

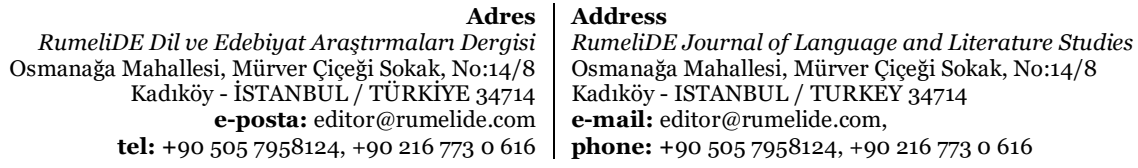

RumeliDE Dil ve Edebiyat Araştırmalar Dergis tel: +90 505 7958124, +90 2167730616 
Bu kaçış veya firarın menzili konusunda da Asım bir arayış ve sorgulama içindedir. Melankolinin yoğunluk kazandığı dönemlerde ulaşılmak istenen bu mekânın neresi olabileceği konusundaki belirsizlik ve tereddüt, yaradana sığınılarak dile getirilir. 27. 6. 1938 tarihli mektupta Asım, "Nerdeyim Allahım? Yerden uzak göklere yakın, göklerden uzak yere yakın bu yer neresidir?” (Asım, 2015: 98) diye sormaktadır. Ahmet Haşim’in "Yarı Yol" (Haşim, 2020: 139) şiirini çağrıştıran bu ifadeler, şiirlerde muhtelif mekân tahayyülleri üzerinden karşılık bulur. Bu yer bazen yolu unutulan bir ülke, uzak bir iklim veya cenup; bazen de meçhul bir belde, bilinmeyen bir ada veya bir hayâl şehirdir. Başka bir deyişle Asım'ın hayalinde kurduğu ve yaşattığı bir ütopyadır. Nitekim amaçlanan bu mekânın gerçekliği konusunda Asım'ın anlatıcı özneleri de daimi bir tereddüt içindedir. "Gecelerin Gelmiyen Baharı" şiirinde hâkim ama müstağni bir kaynağa bu mekânın varlığını sorması, anlatıcının mütereddit durumunu yansıtır: Sütünü esirgeyen meme, söyle / Var mıdır “Öte”de yer bir kişilik? (Asım, 2015: 34). Perişan ve darmadağın hayatını bir yolculuk arifesi olarak düşünen şairin varmak istediği esas menzilin ölümden ötesi olduğu "Son Günüm İçin" şiirinde doğrudan dile getirilir:

\author{
"Başladı gene düğün \\ Gidiyorlar ölümün \\ Sir dolu ülkesine \\ Geldiyse eğer o gün \\ Beni alıp götürün \\ Ölümün ötesine" (Asım, 2015: 54).
}

Kaçınılmazlığı düşüncesinin kanıksanmasıyla birlikte, ölümün bir “düğün” olarak görülmesi şairin kavuştuğu görece huzuru yansitır. Ancak "sır dolu ülke" olarak nitelendirilmesi, ölüm kavramını Levinas'ın işaret ettiği türden bir kaygı durumu olarak sürekli yürürlükte tutar. Bu kaygının bertaraf edilmesi, ancak "ölümün ötesinde" "asude bahar ülkesi”ne (Beyatll, 2005: 62) ulaşabilmekle mümkün olacaktır. Asım'ın bütün arayışı, çabası bu noktada düğümlenir. Bu düğümün nasıl çözümlendiği ise Asım'la birlikte “ölümün ötesi”ne intikal eden bir sır olarak kalır.

\title{
4. Aşk ve kadın dolayımında yaşamak arzusu
}

Ölüm düşüncesiyle yüzleşilen şok ve öfke evresinden sonra, bu gerçeğin kabullenilmesiyle beraber, Asım'ın gelecek kaygılarından sıyrılmaya çalışarak yaşadığı ana odaklanmaya çalıştı̆̆g görülür. Todd May, kavramı felsefi bağlamda etraflıca tartıştığı Ölüm adlı eserinde, insanların ölümle ve ondan kaynaklanan kaygı durumuyla karşılaşmamak için ölümün farkındalığını azaltan yaşama biçimlerini tercih ettiklerini belirtir (2019: 53). Halit Asım'ın da bu kaygıdan olabildiğince uzaklaşmak için yöneldiği yaşam mecralarından biri karşı cinsle yaşanan duygusal ve tensel münasebetlerdir.

Asım karşı cinsle olan münasebetlerini mektuplarında Niyazi Tunga'ya etraflıca anlatır. Söz konusu münasebetlerin ilk kaydı 23-24. 2. 1938 tarihli mektuptur. Bu mektupta, sinıf tekrarına sebep olacak kadar tutkulu bir gönül ilişsisinden söz edilir. Mektuba yansıyan satırlardan Asım'ın bu durumdan pek şikâyetçi ve pişman olmadığı anlaşılır: "Bugün beni derin bir inkisarı hayâl çukuruna götüren bu aşka bir yılımı da kurban ettim. Bu yıl gene aynı sınıfta okuyorum. Ne çıkar be dostum. Varsın bir güzel beni aldatsın. Ne çıar... Ben onu mezarda bile seveceğim” (Asım, 2015: 87). Sevmek, karşı cinse yönelik arzular beslemek, Asım'ın hayata daha iyimser bakmasını sağlar. Kısıtlı bir zamana ve hasta bir bünyeye sahip olduğunu bilmenin bilinciyle, bu ilişkiye hırsla, açgözlülükle sarılmanın acizliğini de içten içe duymaktadır: "Yorgun vücudu, parça parça dökülen içiyle hayata dönen insan ne kadar açgözlüdür. Aydınlıkları tıkanırcasına teneffüs eden, en küçük zevk incilerini, meçhûl denizlerde mercan arıyan

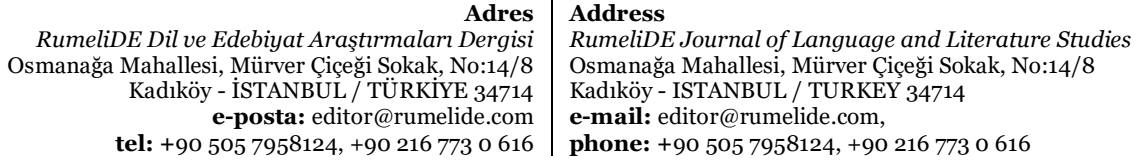


vahşilerin hırsıyla ruhuna doldurmak istiyen insan ne kadar perişandır” (Asım, 2015: 94). Fakat ömrünün en güzel günlerini yaşamın maddi zevkleriyle, aşkla ve kadınla geçirmek konusunda kararlıdır. Bu durum erosun bir telafi aracı olarak görüldüğünü gösterir. Bu kararlılık "Ölesiye" şiirine "Niyetimiz yollarda hep günah izleri, / Ölesiye yaşamak arzusu denizi... (Asım, 2015: 43) dizeleriyle yansır. Yaklaşan ölüm, paradoksal bir şekilde Asım’ı canlandırır, içine gömüldüğü ruhsal sıkışmadan kurtararak kadın dolayımında "başka"ya yönlendirir (Chul-Han, 2019: 10-11). 10. 8. 1938 tarihli mektupta Süveyda'ya dair duygularını kendi durumuyla ilişkili olarak rahatça dile getirmesi, ölüm kaygısının bir hayli azaldığını veya ikinci plana itildiğini yansıtır: "Seviyorum a dostlar, seviyorum... Ölüyor gibi sarıldı ruhum bu aşka... Gün oluyor, adam sen de diyorum[,] üzülecek ne var? Seviyorum, ürperen tüylerimle seviyorum onu. Aşkın ilerisi, gerisi olur mu? Koyver kendini hayatın akışına... Tali[h] hangi limana götürürse götürsün seni...” (Asım, 2015: 104-105).

Yaşama karşı bir iyimserlikten beslenen bu sevinç ve heyecan, Süveyda'ya yazıldığı anlaşlan "Serenat" isimli mensur şiirin atmosfer ve imge ağına yansır. Şiir öznesinin, balkonu altında sevgiliye duygularını açtı̆̆ı zaman dilimi, gece olmasına rağmen, yaşama isteği uyandıracak kadar güzeldir. Atmosferi oluşturan her şey mutluluk ve neşe saçar: Pınarlar şarkı söyler. Saatler, nehirlerde yüzen yapraklar gibi hülyalı ve latif geçmektedir (Asım, 2015: 65). Çiçekli bir tebessümle uyuyan sevgilinin uyanıp balkona gelmesi için anlatıcı bütün söz hünerini sergilemeye çalışır:

"Balkonuna gel sevgilim... Uyan ve bu gece yarısında, kalbini dudaklarından sessiz şarkılar gibi geceye boşaltan, bu karanlıklar adamına bir an görün... (...) Gözlerim kapanmadan seni uyandırıp balkonuna getirmek mümkün olsaydı; kalbimi göğsümden çıkarıp onu keskin bir taş gibi pencerene fırlatmak isterdim..." (Asım, 2015: 66).

Ancak aşkla sevilen, bir melek katına çıkarılan Süveyda’yla ilişkisinin uzun sürmediği takip eden mektuplarla anlaşılır. Bir ay sonraki (5-6 Aralık 1939) mektupta can pahasına sevilen Süveyda'dan, alelâde bir kız olarak söz edilir. Süveyda artık Asım’ın başka kızlara ulaşmasına engel olan “zalim, vahşi bir kuş”tur. Dahası, bir nefret ve öfke nesnesi hâline gelmiştir:

“Gözlerim kovalıyor... Tam tutacağı sırada, o aşka pek lâyık(!) Süveyda[']nın menhus sesi güzelin kulağında çınlıyor; 'Sakın, Halit hastadır, Halit ölecektir, kalp...' Gözler bulanıktır artık, kaçaktır... Çileden çıkıyorum, beynim yanıyor. Her tuttuğum koptu Niyazi. Bütün ruhile karşımda rakseden bir dişidir o... İğreniyorum. Ben ne beyhude imişim meğer. Alelâde[y]i sevmiş olmakla içim titriyor. (...) Avlarımı yuvamdan çalan zalim, vahşi bir kuştur o...” (Asım, 2015: 123).

Süveyda’ya yönelik bu kötücül duygular "Davet" isimli mensur şiire, karanlık ve ürkütücü imajlar üzerinden yansır. Asım’ın uyandırıp balkona çıkarmak için gerekirse kalbini söküp penceresine fırlatacak kadar çok sevdiği bir kadına yönelik duygularındaki bu keskin değişim aşk ve nefret duyguları arasındaki bıçak sırtı yakınlığın bir ifadesi gibidir. İcabet etmenin pek istenmeyeceği bu “Davet”ten alınan aşă̆ıdaki satırlar, şiirin en karanlık ve ürkütücü pasajlarından biridir:

"Etim taş ve toprak olup gezdiğin, yürüdüğün yerlerde ayaklarına diken gibi batacak. Kanım kaynakları, pınar yollarını kirletecek ve sen aldığın her yudumda kanımın kokusunu, onun buruk acılığını hissedeceksin. Ve sonra kemiklerim süğecek. Bazen zehirli cehennem çiçekleri gibi açıp pis kokular yayacak.. Bazen dikenli dallarda çürük meyveler sallanan korkunç bir ağaç halinde pencerene uzanırken göreceksin kemiklerimi” (Asım, 2015: 67).

İlk deneyimin bu duygularla sona ermesinden sonra, Asım'ın karşı cinse yönelik sevgi temelli yaklaşımının salt tensel ve şehevi bir yaklaşımla yer değiştirdiği görülür. Asım’ın kadın algısı içli âşık modundan, Don Juanvari bir şehvetperestliğe kayar. Kadın, gelinen aşamada tensel arzuların doyurulacağı cinsel bir nesne, bir "av" olarak görülür. Yakında öleceğini bilmenin etkisiyle, yaşamdan

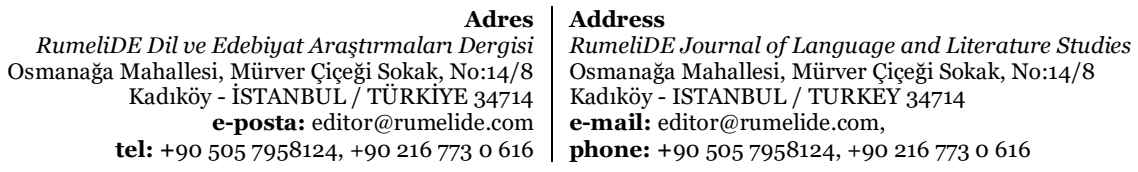


alacaklı gitmemek kaygısı, Asım'da şehevi arzuları her türlü duygusal ve ahlaki tutum hilafına baskın hâle getirir: "Güzelleri seveyim, her şeyine mahkûmiyet duyduğum güzel beni doyursun diyorum. Gözlerim kovalıyor... (...) Oh! Ne olur, ne olur bir güzelin sahibi olsam” (Asım, 2015: 123).

Zaman ilerledikçe, zayıf kalbinin direnci azaldıkça melankolinin yavaş yavaş tekrar güçlenmeye başlaması, karşı cinsle daha karmaşık bir ilişki ağına sebep olur. Asım'ın iç dünyası, üç farklı kadına dair eş zamanlı duygularla çalkalanır. "Süveyda, ebedî bir düşman... Rahmiye, beyhude olmayan yegâne duygu”, Gülten ise vazgeçilemeyen bir baş ağrısı olarak değerlendirilir (Asım, 2015: 128). Bu ifadelerinden de anlaşılabileceği gibi, Asım’ın aşk ve kadın konularındaki yaklaşımı istikrar ve tutarlılıktan yoksundur. Bu yoksunluğun, bütün telafi çabalarına karşın ondaki ölüm kaygısının ve melankolik duyarlığın güçlü oluşundan kaynaklandığı söylenebilir. Bu durum karşısında Asım'ın yöneldiği daha güçlü yaşam tutamaklarından, telafi çabalarından bir diğeri ise istikrarlı dostluk ilişkileridir.

\section{Bir yaşam tutamağı olarak dostluk}

Aristoteles, oğlu Nikomakhos'a ithafen yazdığı Nikomakhos'a Etik adlı eserinde üç tür dostluktan söz eder. İlki birbirinden hoşlanma, zevk alma temeline dayanan hazza/zevke odaklı dostluk; ikincisi ise karşılıklı çıkar esasına dayanan faydacı dostluktur. Bütün insanların yaşamlarında ulaşmayı amaçladığı üçüncü dostluk türü ise hakiki dostluktur. Aristoteles'e göre ilk ikisi salt tesadüflere bağlı olduğu, dostluğun kendisini değil zevk ve faydayı amaçladığı için kahıcı değildir. Hakiki dostluk ise dostluk kavramının kendisini amaçlar. Zevk ve fayda gibi durumlar, gerçek bir dostluk ilişkisinde karşılıklı sevgi ve samimiyetin doğal bir sonucu olarak belirir. İyi ve erdemli bir insan olmanın yolu, der Aristoteles, hakiki dostluk ilişkileri kurabilmekten geçer (Aristoteles, 2019: 174).

Ömür kitabına alınan 45 mektubu, gerek hitap tarzı gerekse içeriğiyle Halit Asım'ın Niyazi Tunga'yla hakiki bir dostluk ilişkisi kurduğuna işaret eder. Bu dostluk, uzun süre farklı şehirlerde yaşamalarına, fazla bir araya gelme imkânı bulamamalarına rağmen mektuplar üzerinden Asım'ın ölümüne kadar devam eder. Arif Damar'ın aktardığına göre bu mekânsal uzaklığa rağmen “ölümünde bile Niyazi Tunga [Halit Asım'ın] yanında, yakınındadır” (1989: 14). Tunga'nın dostluğu, melankoliyle mücadelesinde Asım'ın en temel yaşam tutamaklarından biri olur. Niyazi Tunga'yla olan bu duygusal ve düşünsel yakınlığın yoğunluğu, Asım’ın gündelik yaşantısına, aile çevresine, eğitim hayatına, edebiyata, şiire, kitaplara ve yazarlara dair muhtelif konular üzerinden izlenebilir. Ancak, bu duygusal ve düşünsel yakınlık, özellikle Asım’ın hastalığından ve ölüm kaygısından bahsettiği mektuplarda yoğunlaşır. 23-24. 2. 1938 tarihli mektupta Asım, hastalığının yol açtığı karamsarlığı dile getirirken Tunga’yı gerek hekim oluşu gerekse yazdıklarıyla bir şifa kaynağı olarak görür:

“Ah! Ben gülmeyi çoktan unuttum kardeş... Gülebilsem de gülmem sana. Yalvarırım beni tedavi et. Ben hastayım, bunu biliyorum. Senin gibi iyi dostlara en muhtaç olduğum anların içindeyim. Doktorluğunun ilk manevi tedavisine benim ruhumda başla ne olur” (Asım, 2015: 85).

Yaşamının hastalık ve ölüm karşısındaki kırılganlığıyla baş edebilmek için bu dostluğun daimi olmasını diler: "Hastalı̆̆ımdan içim çürüyerek, dudaklarım ezilerek bahsetmeyi ne kadar geciktirirsem o kadar az yaralanıyor, az çöküyor ve ölümden o kadar çok uzaklaşmış oluyorum. Benimle beraber ol” (Asım, 2015: 95). Asım için Tunga, yaşadığı hayata tahammül edebilmesini sağlayan en önemli varlıktır. Mektuplarından anlaşlabildiği kadarıyla Niyazi Tunga ona ailesinden bile daha yakındır. Haziran 1941 tarihli son mektubunda "Beni yalnız bırakmamıya çalış! olmaz [mı] Niyazi?" (Asım, 2015: 140) satırları, Asım’ın yaşadığı yalnızlığı ve dostunun, varlığına kattığı yaşama direncini işaretler.

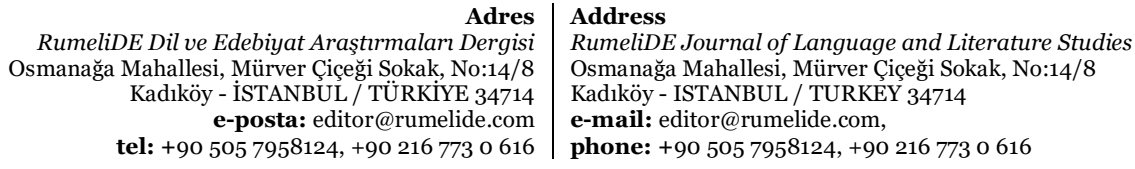


Bu dostluğun izlerinin şiirlere çok yoğun ve doğrudan yansıdığı söylenemez. İçerik olarak Asım’ın iç dünyasını, melankolik hayat algısını yansıtan "Gönül” isimli şiirin, Niyazi Tunga'ya ithaf edilmesi bu dostluğun yoğunluğunun bir göstereni olarak değerlendirilebilir. Bu şiir, henüz yazım aşamasındayken Tunga'ya gönderilen mektuplardan birinde yer alır. Bitince dostuna ithaf edileceği ve şiirin onun tarafından isimlendirileceği de belirtilir (Asım, 2015: 126). Aynı mektupta Ziya Arıkan'a ithaf edildiği ve onun tarafından isim konacağı söylenen şiir ise, Arıkan'la olan iletişimin ve dostluğun bitmesinden dolayı sonradan "Sabır" adıyla fakat ithafsız olarak yayımlanır.

Asım’ın "bizim şiirimizdir" (Asım, 2015: 138) dediği “Üç Arkadaş" bu dostluğu doğrudan yansıtan tek şiirdir, denebilir. Dostlarına dair duyguların idaresinde gelişen şiir Asım’ın yaşama karşı iyimser tavrını yansıtır. Şiir, dört farklı resmin içerdiği manzaralar üzerinden Asım’ın dostlarıyla birlikte hayalini kurduğu yaşamı serimler. İlkinde, akşam vakti kızıl bir mezarlıkta yürüyen bir ihtiyar resmedilir: "Birisinde akşam oluyor, / Taşları kızıl bir mezarlık; / Mezarlıkta yürüyen bir ihtiyar" (Asım, 2015: 61).

$\mathrm{Bu}$ manzara, ihtiyarla temsil edilen ölüm düşüncesinin yol açtığı hüznü ima etse de takip eden resimlerdeki şarkı söyleyen balıkçılar, denizi seyreden ufuk kokulu çocuklar, kayıkları dolduran şarkılar bu hüznü ve karanlığı dağıtmaya yetecektir: "Dağıtırız bu dört resimde hüznümüzü, / Şarkılar kayıkları doldurur; / Ve ufuk kokulu çocuklar gündüzümüzü.” (2015: 61).

$\mathrm{Bu}$ manzaralar içinde dostlarla birlikte yaşamak uzun bir ömrü muştular. Dostlarla birlikte yaşam sürdüğü sürece umut vardır. Böyle bir umut ise Asım’ı ölüm karşısında kapıldığı elemden, kaygı durumundan kurtaracak, onu hayatla barıştıracak yegâne vesile olacaktır: "İhtiyar çok yaşayacak, / Ve biz bir dua gibi bırakacă̆ız, / Kendi denizimizden şikâyeti” (2015: 61).

Şiirlerde çok fazla dile getirilmese de mektuplarda Asım'ın dostu Niyazi Tunga'yla şiir ve edebiyat konularında sürekli fikir ve öneri alışverişinde bulunduğu görülür. Dostunun önerdiği yazar ve kitaplar, yaşadığı kasveti ve kötümserliği dağıtıp ona ümit aşılar. Özellikle Necip Fazıl Kısakürek’in Bir Adam Yaratmak oyununun ana karakteri Hüsrev ve George Duhamel'in Geceyarısı İtirafi romanının ana karakteri Salavin'le dostunun önerisiyle tanışır. İki karakter de "bir gece yarısı kadar karanlık ve mütereddit bir ruhun bütün ıztıraplarını anlat[masıyla]" (2015: 89) Asım'ın içinde bulunduğu durumu anlamasına yardımcı olur. Bu anlamda şiir ve edebiyatın hem Tunga'yla dostluğunu pekiştiren hem de Asım'ın biteviye yaşadığı ölüm kaygısını hafifleten ortak payda ve en temel telafi çabası olduğunu söylemek gerekir.

\section{Sonuç}

Halit Asım’n kısa yaşamını ve şiirini etkileyen hastalık ve ölüm kavramlarından menkul melankoliyi, bununla başa çıkma çabalarını şiirleri ve mektupları bağlamında incelemeyi amaçlayan bu çalışma neticesinde aşağıdaki tespit ve sonuçlara varıldı.

Cumhuriyet Dönemi Türk şiirinin gölgede kalmış şairlerinden biri olan Halit Asım hakkındaki ortak kanı, onun "sükût suikasti"ne uğramış bir şair olduğu yönündedir. Şairin Ömür adlı tek şiir kitabı ölümünden bir yıl önce, 1940’ta yayımlanır. Kanona eklemlenen şiirler yazarak ilgi devşirmek yerine alabildiğine bireysel ve içe dönük bir şiir tarzını sürdürmek, Asım’ın görmezden gelinmesine zemin hazırlar. Henüz sekiz yaşındayken yakalandığı "adali romatizma”nın yol açtığı kronik kalp hastalığı şairin yirmi üç yıllık yaşamını şekillendiren en temel olaydır. Bu hastalık, Asım’ın ölüm kavramıyla yaşamının çok erken bir evresinde tanışmasına yol açar. Bugün kolayca tedavi edilebilen bu hastalıktan

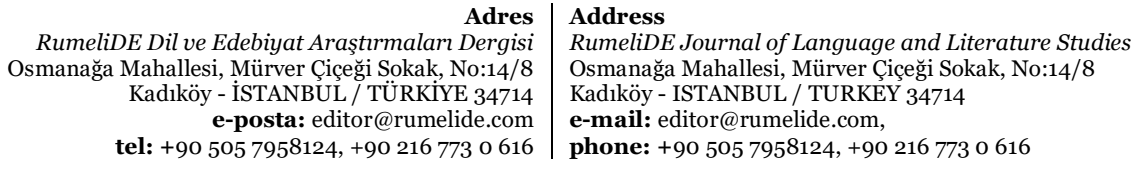


ileri gelen ölüm korkusu, Asım'ın hayatını ve şiirlerini şekillendiren başlıca etken olur. Dostu Necati Tunga'ya yazdığı mektuplarda, bu hastalığın ve yol açtığı kaygı ve korkuların seyri kronolojik olarak takip edilebilir. Asım'ın hastalı̆̆ına ve ölüm korkusuna dair düşünceleri sabit bir seyir izlemez. Mektupların genel tonu elem ve karamsarlık duygularını içerse de ara ara iyimser duygular da ifade edilir. Ancak bu iyimser ruh hâli istikrardan uzaktır. Küçük bir ayrıntı veya çağrışımla derhâl acı ve huzursuzlukla yer değiştirir.

Ölüm kaygısı, Asım'ın şiirlerini de bütünüyle kuşatır. Yaklaşan ölümün uyandırdığı kayıp ve hüsran duyguları şiirler aracılığıyla da kayıt altına alınır. Bu kaygının şairde yarattığı ruh hâli, bazı şiirlerde yoğunlaşarak bir vehim durumuna dönüşür. Bu duygu durumlarının yoğunluğu ve sürekliliği, Asım'ın yaşamı ve şiirleriyle melankoli kavramı arasında güçlü bir bağ bulunduğuna işareteder. Melankoli, Asım'da iki farklı aşamaya ve karaktere sahiptir. İlk aşama, Asım'ın mizacının bir sonucu olarak yaşanan mahzun ve kötümser ruh hâlini anlamlandırma, "kayıp nesne"yi bulma çabası şeklinde tezahür eder. İkinci aşama ise, bu kayıp nesnenin ölüm düşüncesinde bulunmasının ardından gelişen melankolik duygu ve düşünce durumlarına odaklanır. Dolayısıyla Asım'ın mektuplarında ve şiirlerinde söz konusu olan melankolik durum, mizacından ve ölüm düşüncesinden beslenir. Şairin melankolik mizacından kaynaklı bir anlam arayışıyla başlayan süreç, aradığı anlamı, kayıp nesneyi ölüm düşüncesinde bulur. Kaynağının/nesnesinin belli olduğu bu melankolinin yol açtığı ruhsal basıncı azaltmak, hayata tutunmak için şairin farklı telafi çabalarına giriştiği görülür. Mektupları ve şiirlerinde ön plana çıan yolculuk, kaçış, başka diyarlara özlem arzuları, karşı cinsle yaşanan duygusal ve tensel münasebetler ve istikrarlı dostluk ilişkileri Asım’ın yaşadığı melankoliyi bir nebze de olsa hafifletmek için başvurduğu temel telafi çabaları olarak öne çlkar.

Mektup ve şiirlerinin içerdiği kasvet, yoğun somutlamaya dayalı imge ağı şairin yaşadığı kaygı ve vehmin yazıya düşen izleridir. Kendisi de yazdıklarının dağınıklığını ve düzensizliğini yaşamla olan bağlarının gevşekliğine bağlayarak yazı ile yaşam arasındaki koşutluğa işaret eder. Ancak yazdıklarının dağınık ve gevşek olduğu düşüncesine Asım'ın hilafına şerh düşmek gerekir. Çünkü mektup ve şiirleri, gerek hacim gerekse içerdiği imge yoğun diliyle şairin söz terazisinin çok hassas olduğunu işaret eder. Esasını melankolik mizacından, bir lanet gibi taşıdığı hastalığından ve ölüm düşüncesinden alan şiirlerinin içerdiği karanlık atmosfer ve yoğun imge ağı, Halit Asım’ Cumhuriyet Dönemi Türk şiirinin özgün ve sıra dışı şairlerinden biri olarak değerlendirmeye imkân verir.

\section{Kaynakça}

Aristoteles (2019). Nikomakhos'a Etik. (Çev. Furkan Akderin). İstanbul: Say.

Arslanoğlu, K. (2007). Psikiyatri El Kitabr. İstanbul: İthaki.

Asım, H. (2015) Ömür (Şiirler-1940). İstanbul: Ve.

Batmankaya, M. (1999). “Ac1: Hayat Pastasının Üzerindeki Garnitür”. Varlk, 1106,28-30.

Beyatl, Y. K. (2005). Kendi Gök Kubbemiz. İstanbul: Yapı Kredi.

Burton, R. (2018). Melankolinin Anatomisi. (Çev. Merve Tokmakçıŏlu). İstanbul: Aylak Adam.

Chul-Han, B. (2019). Eros'un Istrrabı. (Çev. Şeyda Öztürk). İstanbul: Metis.

Damar, A. (1989). “Bizim 'Liseli’miz Halit Asım”. Gösteri, 109, 14-18.

Damar, A. (2006). “Üç Şair”. Yasakmeyve, 21,44.

Durmaz, K. (1989). "Halit Asım, Vehmin Şiiri”. Edebiyat Dostları, 29, 7.

Freud, S. (2014). Yas ve Melankoli. (Çev. Aslı Demirsoy). İstanbul: Telos.

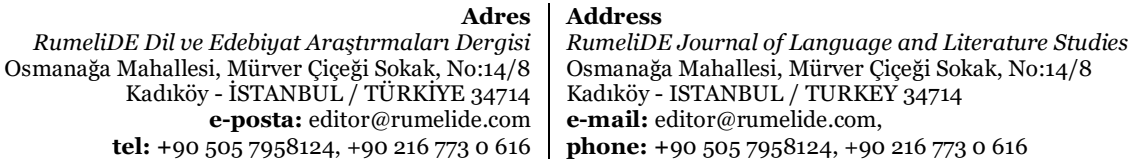


Haşim, A. (2020). Bütün Şiirleri. İstanbul: Kırmızı Kedi.

Kahyaoğlu, O. (1995). "Bu Bir Sahip Çıkış Yazısıdır”. Sombahar, 28, 61.

Korkmaz, F. (2018). Başlangıçtan Cumhuriyet’e Yeni Türk Şïrinde Melankoli. İstanbul: Grafiker.

Kristeva, J. (2009). Kara Güneş-Depresyon ve Melankoli. (Çev. Nesrin Demiryontan). İstanbul: Bağlam.

Levinas, E. (2014). Ölüm ve Zaman. (Çev. Nami Başer). İstanbul: Ayrıntı.

May, T. (2019). Ölüm-Felsefi Bir Deneme. (Çev. Emre Keser). İstanbul: Say.

Teber, S. (2013). Melankoli, İstanbul: Say.

Wittmann, M. (2018). Hissedilen Zaman. (Çev. Özge Duygu Gürkan). İstanbul: Metis.

RumeliDE Dil ve Edebiyat Araştırmaları Dergisi Osmanağa Mahallesi, Mürver Çiçeği Sokak, No:14/8 Kadıköy - İSTANBUL / TÜRKIYE 34714 e-posta: editor@rumelide.com tel: +90 $5057958124,+902167730616$
Address

RumeliDE Journal of Language and Literature Studies Osmanağa Mahallesi, Mürver Çiçeği Sokak, No:14/8

Kadıköy - ISTANBUL / TURKEY 34714

e-mail: editor@rumelide.com,

phone: +90 505 7958124, +90 2167730616 